Rechel, B., Mladovsky, P., Devillé, W. Monitoring migrant health in Europe: a narrative review of data coltecti practices. Health Policy: 2012, 105(1), 10-16

\begin{tabular}{|l|l|}
\hline Postprint Version & 1.0 \\
\hline Journal website & $\underline{\text { http://www.sciencedirect.com/science/article/pii/S0168851012000048 }}$ \\
\hline Pubmed link & $\underline{\text { http://www.ncbi.nlm.nih.gov/pubmed/22277878 }}$ \\
\hline DOI & $10.1016 / \mathrm{j}$. healthpol.2012.01.003 \\
\hline
\end{tabular}

This is a NIVEL certified Post Print, more info at http://www.nivel.eu

\title{
Monitoring migrant health in Europe: A narrative review of data collection practices
}

\author{
BERND RECHEL ${ }^{\mathrm{A}, \star}$ PHILIPA MLADOVSKY ${ }^{\mathrm{B},}$ WALTER DEVILLÉ ${ }^{\mathrm{C}, \mathrm{D}}$ \\ ${ }^{a}$ European Observatory on Health Systems and Policies, London School of Hygiene \& Tropical Medicine, \\ 1517 Tavistock Place, London WC1H 9SH, United Kingdom \\ ${ }^{b}$ LSE Health, European Observatory on Health Systems and Policies, London School of Economics and \\ Political Science, Houghton Street, London WC2A 2AE, United Kingdom \\ c University of Amsterdam, Department of Sociology and Anthropology, Amsterdam Institute for Social \\ Science Research (AISSR), The Netherlands d NIVEL (Netherlands Institute for Health Services \\ Research), Otterstraat 118124, Post Box 1568, 3500 BN Utrecht, The Netherlands
}

\begin{abstract}
A B S T R A C T
Background: Data on the health of migrants, including on health determinants and access to health services, are an essential precondition for providing appropriate and accessible health services to this population group. This article reviews how far current data collection systems in the European Union (EU) allow to monitor migrant health. Methods: We searched the academic literature using PubMed and reviewed the results of recent EUfunded research projects on migrant health. Results: Most EU member states lack information on the health of migrants, limiting the possibility for monitoring and improving migrant health. National death registers allow for disaggregation according to migrant status in 24 of $27 \mathrm{EU}$ member states. Registry data on health care utilization by migrant status are available in only 11 of 27 member states, although in most cases this only covers secondary and not primary care. Only few countries collect largescale survey data on migrant health and health care utilization. Conclusion: Many EU countries need to step up their organizational and regulatory efforts to monitor migrant health if the current lack of data on migrant health should be overcome. This could be done through the inclusion of improved questions on migration in existing data collection processes.
\end{abstract}

\section{INTRODUCTION}

Accurate data on the health of migrants, including on health determinants and use of health services, are an essential precondition for monitoring and improving health and providing appropriate and accessible health services to this population group. The need for better data on migrant health has been recognized for some time. Already in 1983, a consultation of the World Health Organization (WHO) on health and migration recommended more indepth studies on differences in mortality and morbidity ${ }^{[1]}$. This was further underlined by the 2008 WHO resolution on the health of migrants ${ }^{[2]}$ and the European Union (EU) level consultation on "Migration Health - Better Health for All" in $2009^{[3]}$, as well as by the Council of Europe ${ }^{[4-6]}$. This article reviews current data information systems and recent research activities in the EU and how far they make it possible to assess and monitor migrant health. 
Rechel, B., Mladovsky, P., Devillé, W. Monitoring migrant health in Europe: a narrative review of data collecti practices. Health Policy: 2012, 105(1), 10-16

\section{MATERIAL AND METHODS}

This paper forms part of a wider study on "Migration and health in the European Union”, undertaken by the EuropeanObservatory on Health Systems and Policies, the International Organization for Migration, and the EUPHA Section on Migrant and Ethnic Minority Health in 2010-2011 ${ }^{\text {[7] }}$. The study aimed to draw together available evidence on key aspects of health and migration in the European Union through a series of comprehensive literature reviews. In this paper we present findings related to data infor mation systems and research activities on monitoring migrant health. Our concern was with data collection sys tems that elicited migrant status and thus allowed to distinguish between the migrant and non migrant popula tion. We opted for a narrative review approach, aiming to critically summarize the literature on the topic and to iden tify options for improving data collection on migrant health ${ }^{[8]}$. We searched PubMed using the terms “migrant(s)” AND “data”/“information”/“monitoring” in the title, the terms "asylumseeker” and "victims of trafficking” in all fields, and the MeSH terms "transients and migrants" AND "Europe”/"European Union” in all fields. We included those hits relevant to our topic and published in English since 2000 and excluded papers not specifically concerned with monitoring migrant health, published in other languages or before 2000. We complemented this search with a review of publicly available reports from recent EUfunded research projects of particular relevance to monitoring migrant health: Monitoring the Health Status of Migrants within Europe: Development of Indicators, Migration and Ethnic Health Observatory (MEHO) (led by Erasmus University, Netherlands), Promoting Comparative Quantitative Research in the Field of Migration and Integration in Europe (Prominstat) (led by the Bristol University, United Kingdom), and Assisting Migrants and Communities (AMAC): Analysis of Social Determinants of Health and Health Inequalities (led by IOM Brussels, Belgium). We also included recent publications on migration and health of two relevant international organizations: the International Organization for Migration and the World Health Organization, as well as relevant documents from the EU and the Council of Europe.

\section{RESULTS}

Our search yielded three publications specifically concerned with monitoring migrant health in Europe ${ }^{\text {[9- }}$ ${ }^{11]}$, several research papers investigating the situation in selected EU countries ${ }^{[12-16]}$, a number of outputs from recent EUfunded projects ${ }^{[17-21]}$, several reports from international organizations related to migration and health ${ }^{[1-3,22-25]}$, and a number of relevant documents from the EU and the Council of Europe ${ }^{[4-6,26-29]}$. The information we could retrieve suggests that in most European Union (EU) countries information on the health of migrants is lacking ${ }^{[22,30]}$, limiting the possibility for monitoring and improving migrant health ${ }^{[18]}$. This is due to a number of issues, including the lack of routine data collection on migrant health, either through registry data or regular surveys. In contrast to some "traditional" countries of immigration, such as Australia or New Zealand, most countries in Europe do not routinely collect health data by migrant status in health care utilization registries or through regular surveys. Some countries, such as the Netherlands, Sweden and the United Kingdom, have significant experience in conducting populationbased surveys that also contain information on migrant status, but others, such as Belgium, France, Germany and Spain, have only recently started to include such variables in health surveys. The new EU member states generally do not include indicators of migrant status in health surveys. There are also conceptual and methodological challenges in collecting data on migrant health, such as different definitions or understandings of who constitutes a migrant ${ }^{[18]}$ - and how many there are in a given country ${ }^{[16]}$.

\subsection{Conceptual and methodological challenges of data collection}

Countries in the EU differ with regard to categorizations and definitions of migrants, and whether it is deemed acceptable to collect data on them. This is mainly due to different historical contexts, statistical traditions, administrative and political structures, welfare regimes and immigration histories ${ }^{[17]}$. A fundamental conceptual problem is the lack of a universally agreed definition of who constitutes a migrant ${ }^{[19]}$. Although the UN ${ }^{[26]}$ aimed to establish a set of common definitions and classifications of migratory movement, data collection is still guided by national legislative, administrative and policy needs ${ }^{[23]}$, and follows national definitions and classifications ${ }^{[1,19]}$. As such, countries define migrants in many different ways, e.g. by country of birth, citizenship, residency, and, less frequently, the duration of stay, and rely on selfidentification ${ }^{[23]}$. This makes it very challenging to measure international migration, not to speak of monitoring migrant health. All the different definitions of migrant status have their limitations ${ }^{[1,12]}$. Both, citizenship and country of birth, do not account for the time of arrival, and thus fail to capture the difference between newly arrived migrants and those who arrived decades ago. Citizenship also fails to account for naturalized migrants, and does not distinguish between nativeborn and foreignborn holders of other 
Rechel, B., Mladovsky, P., Devillé, W. Monitoring migrant health in Europe: a narrative review of data collectipi practices. Health Policy: 2012, 105(1), 10-16

citizenships. Overall, country of birth seems to a better indicator of migrant status than citizenship, as it has the advantage of being objective, stable and comparable and is not influenced by citizenship regulations, although it has the limitation of failing to distinguish between different ethnic groups from the same country of birth. Parental country of birth allows the identification of the firstgeneration descendants of migrants ${ }^{[1,12,20]}$. Legal obstacles to the collection of data on migrant status include concerns over data protection, necessitating informed consent of respondents. From a political perspective, in many countries collection of data on migrant status is more acceptable than collection of data on ethnicity ${ }^{\text {[31] }}$. For example, in France, in line with the republican ideology of "all citizens are equal”, routine data collection systems such as the national census only refer to citizenship and country of birth and do not ask any questions about ethnicity or religion ${ }^{[19]}$. In Germany, no "ethnic” data are collected officially ${ }^{[27]}$, in part due to concerns that such data might evoke memories of the categorizations used under National Socialism and could be misused to incite racism and discrimination. In contrast, some European countries collect data on ethnicity, although this comes with additional challenges, such as how to categorize ethnic groups for selfidentification ${ }^{[32,33]}$. In the United Kingdom, for example, the communities largely established through migration from former colonies after the Second World War and subsequent waves of immigration are referred to as "black and minority ethnic" (BME) groups ${ }^{[34]}$. However, ethnicitybased data alone cannot be used to ascertain migrant status. An added complication is that the term "migrants" is used in the United Kingdom only for recent arrivals ${ }^{[35]}$. In the Netherlands, surveys collect information not only on country of birth, but also on parental country of birth; those born outside the Netherlands, or with at least one parent born outside the country, are collectively classified as “allochtonen” (i.e. of foreign origin) ${ }^{[36,37]}$. Another problem is that the commonly used definitions of migrant status do not distinguish between the many subcategories of migrants, such as asylumseekers, irregular migrants, victims of trafficking, economic migrants and students. In migrant health research this poses a problem because these groups face specific health needs ${ }^{[38]}$ and may face particular legal barriers in accessing health services ${ }^{[39]}$. In addition, the health effects of migration often extend beyond the first generation, with second and third generations sometimes facing particular health issues, making it desirable to collect data in such a way that can capture this variation $^{[1]}$. Another limitation of the migrant health data that are being collected in Europe is that, until recently, the focus has typically been on specific diseases or conditions, particularly communicable disease ${ }^{[1]}$. Research on social determinants of health, entitlements to health care, specific interventions, and general accessibility and quality of care is still rare ${ }^{[19]}$. Another common problem in migrant health research is that the denominator, i.e. the size of the underlying population, is unknown due to the presence of undocumented migrants and the general poor quality of data ${ }^{[24]}$. Even where this information is available, data may be misleading, if not adjusted for age, sex and socioeconomic status. Indeed, migrants themselves may be reluctant to reveal information on their migrant status or related variables. They may - not without justification ${ }^{[28]}$ - fear discrimination, stigmatization, exclusion or, in the case of undocumented migrants, even denunciation and deportation ${ }^{[1,19,25]}$. After all, much historical research on race and ethnicity in Europe and elsewhere was racist and unethical ${ }^{[40]}$. Yet, without information on migrant status it is impossible to monitor and improve migrant health. The heterogeneity and relatively small size of migrant communities is a factor as well, as oversampling would often be required in surveys or clinical studies to yield statistically relevant information ${ }^{[36]}$. Access to some populations, such as undocumented migrants, is another obstacle to research on migrant health. Finally, much research on migrant health is confined to the grey literature, not translated into English and does not inform future research or policymaking in other countries ${ }^{[19]}$.

\subsection{Registry or census data}

\subsubsection{Sociodemographic data}

In most countries, general background information on the number and sociodemographic characteristics of migrants is routinely collected by national authorities, such as through censuses. Although census data on citizenship or place of birth have considerable limitations, they can be used to provide rough estimates of the size and demography of migrant populations and to plan health policies ${ }^{[1]}$. A challenge, however, is to link this information on a subject level to data collected in registers on diseases or health care utilization. In several Nordic countries, this linkage is possible, opening possibilities for registerbased research on migrant health ${ }^{[13]}$.

\subsubsection{Mortality data}


Rechel, B., Mladovsky, P., Devillé, W. Monitoring migrant health in Europe: a narrative review of data collectipi practices. Health Policy: 2012, 105(1), 10-16

Health information systems in most European countries are generally not designed to identify people by migrant status and the information collected in medical files rarely includes information on migrant status ${ }^{[20]}$. An exception in many countries is death registers, which often include indicators of migration. A study on the availability of largescale epidemiological data on cardiovascular diseases and diabetes among migrants and ethnic minorities in the EU found that national death registers that allowed for disaggregation according to migrant status were available in 24 countries. Country of birth was used as an indicator in 15 countries, citizenship in 8 countries, and nationality in 7 countries (some countries used more than one indicator) ${ }^{[9]}$. Yet, a complicating factor affecting analysis of mortality data is that migrants often return home when they become old or sick ${ }^{[19]}$, so that death registerbased studies may underestimate migrant mortality ${ }^{[21]}$.

\subsubsection{Morbidity data}

Diseasespecific, populationbased registers on cardiovascular diseases and diabetes with data on migrant status are available only in Germany, England, Scotland and Sweden ${ }^{[9]}$. A survey in 2007 found that cancer registries in many European countries collected information on country of birth, but that migrantspecific analyses were rarely done ${ }^{[41]}$. In contrast, more information is available on infectious diseases, a traditional concern of migrant health research. Information on the epidemiology of these diseases among migrants, in particular with regard to tuberculosis and HIV/AIDS, can be derived from national surveillance systems that detect the "origin" of cases ${ }^{[11]}$. For example, since 2000, information has been collected at the European level on the origin of HIV/AIDS cases, referring to the broad geographical origin of reported cases. The European Centre for Disease Prevention and Control recommends deriving this information from citizenship ("nationality") or country of birth data; if information on both citizenship and country of birth are available, it recommends the use of citizenship ${ }^{[42]}$.

\subsubsection{Health care utilization data}

Although health care utilization data can be an important source of information on migrant health, utilization levels cannot be equated with health needs, as migrants may face barriers in access ${ }^{[19]}$. In addition, the utilization of health services may not always be properly monitored and recorded, in particular where there is a combination of providers, including the private sector and civil society ${ }^{[1]}$. In 2008-2009, registry data on health care utilization that allowed for identification of migrants at national or regional level were only available in 11 of the 27 EU member states: Austria, Belgium, Denmark, Finland, Greece, Italy, Luxembourg, the Netherlands, Poland, Slovenia and Sweden ${ }^{[10]}$. In all 11 countries, utilization data were available for hospital care (although with varying detail), while only few countries collected data on care in outpatient settings. The different categorizations of migrants in EU countries also affect the information collected in registry data on health care utilization: five of the 11 countries mentioned above collected data on both citizenship and country of birth, one only on country of birth, and five collected data only on citizenship ${ }^{[10]}$.

\subsubsection{Survey data}

In addition to registry data collected in censuses, death registers, disease surveillance or health care utilization, many governments commission surveys on representative samples of the population, which sometimes contain information on migrant status. Surveys include health surveys (including health interview surveys and health examination surveys), as well as surveys concerned with broader information that also contain some information on health, such as living standard surveys. Illustrative examples for surveys conducted in various European countries include the 2006 Children and Adolescent Health Survey in Germany, which included questions on country of birth (including from parents) and biomedical measurements, such as of height, weight and body mass index. In Sweden, an annual survey on living conditions also collects information on selfassessed health and country of birth ${ }^{[37]}$. Sometimes, more general surveys are supplemented by targeted surveys aimed at hardtoreach groups and qualitative investigations ${ }^{[25]}$. Another source of information are epidemiological studies of population samples based on medical diagnoses and information on migrant status. However, they are confronted with the challenge that migrants may face barriers in access to health services and thus appropriate diagnoses and that the size of the underlying population is often unknown ${ }^{[19]}$. In 2009, epidemiological studies on cardiovascular disease that allowed for the identification of migrant status were available in England, Germany, the 
Rechel, B., Mladovsky, P., Devillé, W. Monitoring migrant health in Europe: a narrative review of data coliectip practices. Health Policy: 2012, 105(1), 10-16

Netherlands, Sweden and Wales, but only the Dutch National Survey on Morbidity Interventions in General Practice was nationally representative ${ }^{[9]}$. The migrant data collected from surveys typically have serious limitations, such as low response rates, small sample sizes, and being conducted only in the dominant language of the respective country; combined with the definitional weaknesses discussed above this makes it difficult to use these data to measure the health of migrants compared to the "native" population. Several European countries, including Denmark, the Netherlands, Sweden and the United Kingdom, have undertaken a number of surveys that contain information on the health of migrants ${ }^{[19,21]}$, but much information is now outofdate. For example, in England, survey data on health disaggregated by country of birth (including parental country of birth) are collected annually in the Health Survey for England. In 1999 and 2004, the survey had a special focus on "minority ethnic groups", boosting their numbers in order to draw statistically relevant conclusions ${ }^{[43]}$. In the Netherlands, data on migrant utilization of health services have been collected at both primary and secondary level. However, primary care data were last collected by the Second Dutch National Survey of General Practice in 2000-2002. Data on hospital utilization are also collected, but face the problem of low levels of response ${ }^{[37]}$. The abovementioned study on the availability of largescale epidemiological data on cardiovascular diseases and diabetes among migrants and ethnic minorities in the EU could identify relevant health survey data in only six of 27 countries; data from nationally representative health examination surveys were available in England, France and Scotland. Nationally representative health interview surveys were conducted in Belgium, Denmark, England, France, Italy, Northern Ireland, Portugal and Wales ${ }^{[9]}$.In sum, only few countries collect largescale survey data on migrant health and health care utilization. The variation in migration indicators used makes it difficult to use national surveys for crosscountry comparisons, which could be useful for designing policy interventions at the European level and to benchmark how well health systems respond to the needs of migrants in different countries, in particular where migrants come from the same country of origin and share other characteristics ${ }^{[14,15]}$. More comparable data across the EU can be derived from European surveys using the same indicators across countries ${ }^{[20,21]}$. Much will depend on response rates and sample sizes of migrants covered by these surveys $\left({ }^{\text {Table } 1}\right)$. Of the Europewide surveys, SHARE has the richest information on health, but is confined to the population over 50 years of age and has smaller samples from each country, leading to a limited applicability in migration issues. EUSILC and ECHP (with last surveys for the latter collected in 2001) have larger samples and cover all age groups, but contain more subjective indicators on health, based on selfreporting ${ }^{[20]}$. Indeed, one of the major challenges with populationbased surveys is that, as health interview surveys, they are often confined to subjective measures of health, such as selfreported health, with major question marks over crosscultural validity ${ }^{[19]}$. As noted above, low response rates among migrants are another problem ${ }^{[20,37]}$.

\subsubsection{European research projects}

A number of projects related to migrant health were funded by the European Commission in the 2000s, including two specifically aimed at improving the evidence base on migrants and their health status ${ }^{[44]}$ :

\section{[TABLE 1]}

- Monitoring the Health Status of Migrants within Europe: Development of Indicators. Migration and Ethnic Health Observatory (MEHO) (led by Erasmus University).

- Promoting Comparative Quantitative Research in the Field of Migration and Integration in Europe (Prominstat) (led by Bristol University). Several of the studies quoted in this article have been the result of these research initiatives. Yet, while the EU has supported research on migrant health, overall cohesion and direction was sometimes missing, as efforts were fragmented between different agencies of the European Commission, as well as between ECfunded projects and those initiated by IOM, WHO or others ${ }^{[19]}$. In addition, project findings and results from surveys coordinated by the European Commission are not always easily accessible ${ }^{[18,45]}$.

\section{DISCUSSION}

This article has reviewed the availability of migrant health data in the EU and some of the challenges involved in improving data collection. One of its limitations is that we have not been able to analyse relevant reports in national languages. Notwithstanding this limitation, this study suggests that, at present, most EU countries do not collect data on migrant health in health care utilization or disease registers, and those that do use different categorizations and definitions, so that data are not always comparable across countries. Many countries in Europe need to step up their organizational and regulatory efforts to monitor 
Rechel, B., Mladovsky, P., Devillé, W. Monitoring migrant health in Europe: a narrative review of data collectipi practices. Health Policy: 2012, 105(1), 10-16

migrant health if the current lack of data on migrant health should be overcome. There is a clear need for standardized data categories and definitions, and the inclusion of improved questions on migration in existing data collection processes, such as censuses and health surveys, as well as in the collection of information on health care utilization ${ }^{[20,25]}$. Ideally, this should put minimal additional requirements on existing data collection systems, allow assessment of duration of stay, include descendants of migrants, and be uniform across Europe ${ }^{[46]}$. However, this article has shown that this will not be an easy task, as categorizations and definitions are often related to dominant perceptions of national identity and specific immigration contexts and histories. Apart from stepping up Europeanwide surveys, the development and implementation of EU guidance or legislation on data collection on migrant health might be one option to improve the standardization of data collection and the comparability of data. The EU has funded several projects for improving data collection on migrant health, but there is substantial scope for developing migrant health research further, including through increased collaboration at the European level and forging a consensus on data collection. An overall European vision on the collection of migrant health data, agreed with other major stakeholders such as IOM and WHO, would help to ensure a more coherent approach to improving the monitoring of migrant health in Europe.

Conflicts of interest: None declared.

Source of support The work of BR and PM is supported by the European Observatory on Health Systems and Policies. The work of PM was also supported by the project 'Health Status and Living Conditions' (VC/2004/0465) for the European Commission, DG Employment and Social Affairs, under the European Observatory on the Social Situation.

Acknowledgements We are grateful to Marieke Verschuuren and to the anonymous reviewers for their helpful comments on earlier versions of this manuscript.

\section{REFERENCES}

[1] Gushulak B. Monitoring migrants' health. In: WHO, editor. Health of migrants - the way forward. Report of a global consultation, Madrid, Spain, 3-5 March 2010. Geneva: World Health Organization; 2010. p. $28-42$.

[2] World Health Assembly. Health of migrants, resolution 61.17. Geneva: World Health Organization; 2008.

[3] International Organization for Migration. Migration health: better health for all in Europe. Brussels: International Organization for Migration; 2009.

[4] Council of Europe. Bratislava declaration on health, human rights and migration. In: 8th Conference of European Health Ministers. 2007.

[5] Committee of Ministers. Recommendation Rec(2006)18 of the Committee of Ministers to member states on health services in a multicultural society. Strasbourg: Council of Europe; 2006.

[6] European Commission against Racism and Intolerance. General policy recommendation no. 1. Strasbourg: Council of Europe; 1996.

[7] Rechel B, Mladovsky P, Devillé W, Rijks B, PetrovaBenedict R, McKee M, editors. Migration and health in the European Union. Maidenhead: Open University Press; 2011.

[8] Mays N, Pope C, Popay J. Systematically reviewing qualitative and quantitative evidence to inform management and policymaking in the health field. Journal of Health Services Research and Policy 2005;10(Suppl. 1):6-20.

[9] Rafnsson S, Bhopal R. Largescale epidemiological data on cardiovascular diseases and diabetes in migrant and ethnic minority groups in Europe. European Journal of Public Health 2009;19(5):484-91.

[10] Nielsen S, Krasnik A, Rosano A. Registry data for crosscountry comparisons of migrants' healthcare utilization in the EU: a survey study of availability and content. BMC Health Services Research 2009;9(210).

[11] Del Amo J, Bröring G, Hamers F, Infuso A, Fenton K. Monitoring HIVIAIDS in Europe's migrant communities and ethnic minorities. AIDS 2004;18:1867-73.

[12] Stronks K, KuluGlasgow I, Agyemang C. The utility of 'country of birth' for the classification of ethnic groups in health research: the Dutch experience. Ethnicity and Health 2009;14(3):255-69.

[13] Norredam M, Kastrup M, HelwegLarsen K. Registerbased studies on migration, ethnicity, and health. Scandinavian Journal of Public Health 2011;39(7 Suppl.):201-5.

[14] Agyemang C, Kunst A, Bhopal R. A crossnational comparative study of blood pressure and hypertension between English and Dutch SouthAsian and Africanorigin populations: the role of national context. American Journal of Hypertension 2010;23(6):639-48. 
Rechel, B., Mladovsky, P., Devillé, W. Monitoring migrant health in Europe: a narrative review of data collectipi practices. Health Policy: 2012, 105(1), 10-16

[15] Agyemang C, Stronks K, Tromp N. A crossnational comparative study of smoking prevalence and cessation between English and Dutch South Asian and African origin populations: the role of national context. Nicotine and Tobacco Research 2010;12(6):557-66.

[16] Aung N, Rechel B, Odermatt P. Access to and utilisation of GP services among Burmese migrants in London: a crosssectional descriptive study. BMC Health Services Research 2010;10(285).

[17] Kraler A, Reichel D. Quantitative data in the area of migration, integration and discrimination in Europe - an overview. Promoting comparative quantitative research in the field of migration and integration in Europe (PROMINSTAT) working paper no. 01. Brussels: European Commission; 5182010.

[18] Kraler A, Reichel D. Statistics on migration, integration and discrimination in Europe. PROMINSTAT final report. Brussels: European Commission; 2010.

[19] Ingleby D, European Research on Migration and Health. Background paper developed within the framework of the IOM project "Assisting Migrants and Communities (AMAC): analysis of social determinants of health and health inequalities". Geneva: International Organization for Migration; 2009.

[20] Juhasz J, Makara P, Taller A. Possibilities and limitations of comparative research on international migration and health. Promoting comparative quantitative research in the field of migration and integration in Europe (PROMINSTAT) working paper no. 09. Brussels: European Commission; 2010.

[21] Mladovsky P. Research note: migration and health in the EU. Brussels: European Commission; 2007.

[22] Padilla B, Miguel JP. Health and migration in the EU: building a shared vision for action. In: Fernandez A, Miguel JP, editors. Health and migration in the European Union: better health for all in an inclusive society. Lisbon: Instituto Nacional de Saude Doutor Ricardo Jorge; 2009. p. 8-14.

[23] International Organization for Migration. World migration report 2010. The future of migration: building capacities for change. Geneva: International Organization for Migration; 2010.

[24] WHO. How health systems can address health inequities linked to migration and ethnicity. Copenhagen: WHO Regional Office for Europe; 2010.

[25] WHO. Health of migrants - the way forward. report of a global consultation, Madrid, Spain, 3-5 March 2010. Geneva: World Health Organization; 2010.

[26] European Parliament and Council of the European Union. Regulation (EC) No 862/2007 of the European Parliament and of the Council of 11 July 2007 on Community statistics on migration and international protection and repealing Council Regulation (EEC) No 311/76 on the compilation of statistics on foreign workers. Official Journal of the European Union 2007;L 199/23. EN(31.7.2007).

[27] Simon P. "Ethnic" statistics and data protection in the Council of Europe countries. Study report. Strasbourg: Council of Europe; 2007.

[28] European Union Agency for Fundamental Rights. Annual report 2010. Vienna: European Union Agency for Fundamental Rights; 2010.

[29] ECDC. Tuberculosis surveillance in Europe 2008. Stockholm: European Centre for Disease Prevention and Control; 2010.

[30] Rafnsson SB, Bhopal RS. Migrant and ethnic health research: report on the European Public Health Association Conference 2007. European Journal of Public Health 2008;122:532-4.

[31] Johnson MRD. Making difference count: ethnic monitoring in health (and social care). Radical Statistics 2008;96:38-45.

[32] Bhopal R. Glossary of terms relating to ethnicity and race: for reflection and debate. Journal of Epidemiology and Community Health 2004;58(6):441-5.

[33] Aspinall P. The utility and validity for public health of ethnicity categorization in the 1991, 2001 and 2011 British Censuses. Public Health 2011;125(10):680-7.

[34] Iqbal G, Gumber A, Johnson MRD, Szczepura A, Wilson S, Dunn JA. Improving ethnicity data collection for health statistics in the UK. Diversity in Health \& Care 2009;6(4).

[35] Jayaweera $\mathrm{H}$. Health and access to health care of migrants in the UK. London: Race Equality Foundation; 2010.

[36] Ingleby D. Getting multicultural health care off the ground: Britain and The Netherlands compared. International Journal of Migration, Health and Social Care 2006;2(3/4):4-14.

[37] Mladovsky P. A framework for analysing migrant health policies in Europe. Health Policy 2009;93(1):55-63.

[38] Loue S, Bunce A. The assessment of immigration status in health research. Vital and health statistics: Series 2 1999;127:1-115.

[39] Watson R. Migrants in Europe are losing out on care they are entitled to. BMJ 2009;339:b3895.

[40] Bhopal R. Is research into ethnicity and health racist, unsound, or important science? BMJ 1997;314(7096):1751-6.

[41] Razum O, Spallek J, Reeske A, Arnold M. Migrationsensitive cancer registration in Europe. Challenges and potentials. Peter Lang: Frankfurt am Main; 2011. 
Rechel, B., Mladovsky, P., Devillé, W. Monitoring migrant health in Europe: a narrative review of data collecti practices. Health Policy: 2012, 105(1), 10-16

[42] ECDC. Migrant health: epidemiology of HIV and AIDS in migrant communities and ethnic minorities in EU/EEA countries. Stockholm: ECDC; 2010.

[43] NHS. Health survey for England; 2011. http://www.ic.nhs.uk/ statisticsanddatacollections/healthandlifestylesrelatedsurveys/healthsurveyforengland [accessed 06.11.11].

[44] Samuilova M, Peiro MJ, Benedict R. Access to health care for undocumented migrants in the EU: a first landscape of NowHereland. Eurohealth 2010;16(1):26-8.

[45] Mladovsky P, Mossialos E, McKee M. Improving access to research data in Europe. BMJ 2008;336:287-8.

[46] Razum O. Of salmon and time travellers - musing on the mystery of migrant mortality. International Journal of Epidemiology 2006;35:919-21 [Commentary].

TABLE

Table 1

Selected European surveys collecting information on health and migration.

\begin{tabular}{|c|c|c|c|c|}
\hline Survey & Migration indicators & Countries & Years & Sample size \\
\hline $\begin{array}{l}\text { European Community } \\
\text { Household Panel (ECHP). } \\
\text { This was a survey based on a } \\
\text { representative panel of } \\
\text { households and individuals } \\
\text { in each country, covering a } \\
\text { wide range of topics: } \\
\text { income, health, education, } \\
\text { housing, demographics and } \\
\text { employment characteristics. }\end{array}$ & $\begin{array}{l}\text { Last foreign country of } \\
\text { residence before } \\
\text { coming to present } \\
\text { country. Foreign } \\
\text { country of birth } \\
\text { Citizenship }\end{array}$ & $\begin{array}{l}\text { Initially } 12 \text { EU member } \\
\text { states, joined later by } \\
\text { Austria, Finland and } \\
\text { Sweden, and then } \\
\text { covering all } 15 \mathrm{EU} \\
\text { member states at the } \\
\text { time }\end{array}$ & $\begin{array}{l}\text { Annually from } 1994 \text { to } \\
2001 \text { ( } 8 \text { waves). }\end{array}$ & $\begin{array}{l}\text { In the first wave in } \\
1994 \text { an overall sample } \\
\text { of about } 60,500 \\
\text { households }\end{array}$ \\
\hline $\begin{array}{l}\text { European Union Statistics on } \\
\text { Income and Living } \\
\text { Conditions (EU-SILC). This } \\
\text { survey aims at collecting } \\
\text { timely and comparable } \\
\text { cross-sectional and } \\
\text { longitudinal } \\
\text { multidimensional microdata } \\
\text { on income, poverty, social } \\
\text { exclusion and living } \\
\text { conditions. The survey } \\
\text { contains the Minimum } \\
\text { European Health Module of } \\
\text { the European Health Survey } \\
\text { System, an EU initiative to } \\
\text { improve the comparability of } \\
\text { health survey data in the EU. }\end{array}$ & $\begin{array}{l}\text { Country of birth } \\
\text { Citizenship }\end{array}$ & $\begin{array}{l}\text { All EU member states } \\
\text { (except Estonia), plus } \\
\text { Norway, Iceland, } \\
\text { Turkey and } \\
\text { Switzerland. }\end{array}$ & $\begin{array}{l}\text { Started in most } \\
\text { countries in } 2004 \text { or } \\
2005 .\end{array}$ & $\begin{array}{l}\text { For the cross-sectional } \\
\text { component, the plans } \\
\text { are to achieve the } \\
\text { minimum effective } \\
\text { sample size of around } \\
121,000 \text { households or } \\
250,000 \text { individuals } \\
\text { aged } 16 \text { and over in the } \\
\text { EU as a whole }\end{array}$ \\
\hline $\begin{array}{l}\text { Survey of Health, Ageing and } \\
\text { Retirement in Europe } \\
\text { (SHARE). This is a } \\
\text { multidisciplinary and } \\
\text { cross-national survey on } \\
\text { health, socio-economic } \\
\text { status and social and family } \\
\text { networks of individuals aged } \\
50 \text { or over. }\end{array}$ & $\begin{array}{l}\text { Country of birth } \\
\text { Year came to live in } \\
\text { country } \\
\text { Citizenship }\end{array}$ & $\begin{array}{l}\text { Eleven countries } \\
\text { contributed data to the } \\
2004 \text { SHARE baseline } \\
\text { study (Denmark, } \\
\text { Sweden, Austria, } \\
\text { France, Germany, } \\
\text { Switzerland, Belgium, } \\
\text { the Netherlands, Spain, } \\
\text { Italy and Greece). } \\
\text { Further data were } \\
\text { collected in 2005-06 in } \\
\text { Israel. The Czech } \\
\text { Republic, Poland and } \\
\text { Ireland joined in 2006. }\end{array}$ & $\begin{array}{l}\text { First wave: 2004-2005 } \\
\text { Second wave: } \\
\text { 2006-2007 } \\
\text { Third wave: } \\
\text { 2008-2009 }\end{array}$ & $\begin{array}{l}\text { More than } 45,000 \\
\text { individuals aged } 50 \text { or } \\
\text { over }\end{array}$ \\
\hline $\begin{array}{l}\text { European Health Interview } \\
\text { Survey (ECHS). This survey } \\
\text { aims to monitor the health } \\
\text { status and health care } \\
\text { utilization in EU member } \\
\text { states. Its basic survey, the } \\
\text { European Core Health } \\
\text { Interview Survey, is } \\
\text { performed Europe-wide } \\
\text { under the responsibility of } \\
\text { Eurostat and covers about } \\
130 \text { questions. }\end{array}$ & $\begin{array}{l}\text { Nationality } \\
\text { Country of birth }\end{array}$ & All EU member states & $\begin{array}{l}\text { The first wave of } \\
\text { surveys was conducted } \\
\text { in } 2009 \text { in a limited } \\
\text { number of countries. } \\
\text { The next round is } \\
\text { planned for } 2014 \text {. }\end{array}$ & \\
\hline
\end{tabular}

Source: Adapted from Refs. [20,21]. 